\title{
Karl Wolfskehl's Response to English-Language Literature
}

Before he came to New Zealand, Karl Wolfskehl's views of literature in English were almost identical to those of Stefan George and probably shaped by them. George was one of the great translators in the history of German poetry, and his versions of Shakespeare's sonnets would have been a life's work for a lesser man. He also studied and translated a number of other English poets, culminating historically with the Pre-Raphaelites and their contemporaries, especially Dante Gabriel Rossetti and Algernon Charles Swinburne. There is also evidence that the Circle was aware of certain English writers of the nineties, such as Edmond Gosse and Ernest Dowson, whom Wolfskehl valued highly.

With one significant exception, before the New Zealand years Wolfskehl's choice of English poets to admire was practically identical with George's. The exception was Byron: as a part of his own polyglot translation activity, Wolfskehl had been creating German versions of Byron's "Hebrew Melodies"1 No doubt the enormous reputation of Byron in Germany had a role to play here, but the specific attraction for Wolfskehl was the word "Hebrew" in the title. He could incorporate these poems into another tradition whose patterns he had always pursued with fascination, and this fascination helped to set him apart from George, even though George was distinctly sympathetic - the tradition of Jewishness interwoven insolubly with the history of European culture. Byron's "Hebrew Melodies" are not very Jewish in subject matter but are rather an attempt to transport into English some of the features he had been told were characteristic of Hebrew verse. This meeting of two cultures, more especially of an oriental and an occidental one, and most specifically of a Hebrew culture with that of a great European poet could not but fascinate Wolfskehl.

From the point of view of the people he came to know in New Zealand, Wolfskehl's image of English literature, climaxing with Swinburne, must have seemed at least fifty years out of date. Victorianism had entered the nadir of its reputation and Swinburne played virtually no role at all in the local view of Englishness. Wolfskehl's

1 For Wolfskehl's own account of the origins of this interest see his letter to Salman Schocken of 16 September 1938 in BaN II, 202. 
admiration and love of Swinburne hardly suffered from that, for in his letters, whenever he comes to write of English verse, Swinburne's name comes out again and again. Nevertheless Wolfskehl's discovery of modern English and American poetry - and to a lesser extent of New Zealand writing - during his eighth decade of life and under considerably adverse conditions is one of the remarkable stories of several that accompany those years. Another such story might be his growing awareness and admiration of twentieth century music as he stayed glued to his radio in Auckland. Of course the most important of these stories is the growth of his own creative work.

Even before he reached New Zealand, in fact during his stay in Sydney on his passage, Wolfskehl "discovered" an English-speaking poet - the Australian Christopher Brennan. Brennan was perhaps still is - an outsider in the Australian scene, a figure of scandal because of his Dionysian life with alcohol and women, but also viewed as odd because of his detailed knowledge of French Symbolism and its successors in Germany, including the George Circle, and his remarkable efforts to introduce Symbolist patterns into Australian verse. This interest set him apart from other Australian - and New Zealand - writers, whose concept of the modern was derived from more purely English and American sources, but it was, of course, precisely what attracted Wolfskehl, who was introduced to Brennan's verse (the man himself had died in 1931) by another Australian lover of European Symbolism, Ralph Farrell. The primary interest for Wolfskehl was a sense that through Cavafy in Greece, and Ady in Hungary, the energies of Symbolism seemed to reach out to the East and then to encompass the globe, with Brennan as the furthest outpost.2 In this way the interest in Brennan is really an extension of Wolfskehl's long-established central European concerns rather than a new awareness of the other.

That kind of awareness naturally took some time to grow. While a passionate belief in the importance of Brennan is expressed as early as September 1938, the lively interest in T. S. Eliot and his successors is first found in the letters some four years later. This interest was clearly aroused by contact with people in Auckland. Although Eliot himself was deeply indebted to the French Symbolists and more especially to such off-shoots as Verlaine and Rimbaud, most

2 See especially the letter to Pannwitz of 21 September 1938, BaN II, 58. Also to Helmut von den Steinen, 29 September 1938, BaN II, 224; and to Walter and Wolfgang Jablonski, both on 6 January 1941 and 14 June 1941, BaN II, 354, 356. 
of his English-speaking followers were more struck by the innovative ways in which he departed from the luxuriating, discursive language of the Victorians (including Swinburne) into a comparatively laconic, reduced, even coded style. Despite some lip-service to the French, these English poets and readers were more fully aware of the Eliot "revolution" within the English language. This AngloAmerican reception of Symbolism, through the mediation of Eliot and Ezra Pound, was in contrast to the way German epigones of Symbolism turned to a more decorated, "Jugendstil" and hermetic manner derived directly from Mallarmé, rather than from Verlaine. By June 1942 we find Wolfskehl telling his close friend Edgar Salin, surprisingly authoritatively, about what is worth pursuing in Anglo-American poetry, and showing a sharp critical grasp of certain values: "Next to Eliot, who is already 60 years old and therefore already not quite true any more [...] there are Auden and Crane, neither of them of the youngest generation either. Hart Crane, who is already dead, is probably the most remarkable; Auden is interesting less because of his political attitudinising and snobbishness than because of the rhythmic subtlety which at least keeps the dissolution of substance inside the bounds of something like poetry and in this he is the most clearly talented of a whole crowd."3 This assessment of Auden seems remarkably percipient in hindsight, since it is closer to recent views of Auden than to the Audenimage (among anglophone critics) of Wolfskehl's own time.

How did this new interest come about? In a letter to Rudolf Laudenheimer at the end of the same month, Wolfskehl mentions a "nice circle" of people "through whom I have at last got some insight into the literary-poetic present" 4 Just as Wolfskehl was discovering more recent poetry in English a group of Aucklanders were discovering him, this exotic, eccentric but clearly erudite man who had come to live in their midst. Some of their names will be mentioned below.

A month later, in fact, Wolfskehl is remarking that, "[h]ere in New Zealand itself promising cultural life is developing around the centrepiece of the Caxton Press in Christchurch. I am in touch with people there and with the Auckland representatives of this good beginning."5 By now he can already claim that "I can now overview the extremely significant lyrical movement since T. S. Eliot."

3 To Edgar Salin, 11 June 1942, BaN II, 158. [All quotations are from the forthcoming English translation of selected letters of Karl Wolfskehl.]

4 To Rudolf Laudenheimer, 30 June 1942, BaN II, 460.

5 To Kurt Wolff, 31 July 1942, BaN II, 513. 
But in the same letter of July 1942 he is also troubled by another aspect of Anglo-American cultural life - its distorted image, as he sees it, of modern German poetry. In several letters over a period of years he complains of the lack of interest in Stefan George and what he believes is an exaggerated interest in Rainer Maria Rilke.

A few days later, on 3 August, Wolfskehl is again imparting to Salin some of the excitement he clearly felt in the discoveries he had made and was still making. 6 He speaks of the writers who have come after Gosse and Dowson, including Lawrence, who was of interest partly because he had married the sister of Wolfkehl's acquaintance Else Jaffé. But he emphasises that Eliot brought something of a new beginning which has offshoots in New Zealand itself, especially in Rex Fairburn. In the same letter he also expresses his complete failure to understand why the English should be so fond of Wordsworth, and has to admit that in spite of his interest "the border between one culture and another often persists".

Finally in this letter he makes two interesting comparisons. One is between Emily Dickinson and Anna Derleth. The latter was the sister of a poet, Ludwig Derleth, who was on the edges of the George Circle and she is referred to by Wolfskehl as "the evil nun", quoting a poem from George's Der Siebente Ring. The points of comparison with Emily Dickinson are her puritanism and her fragmentary manner. A few months later he suggests that his niece, Marie-Luise, would find much of interest in Dickinson. 7 The other comparison he makes is between Francis Thompson's "Hound of Heaven", a poem he consistently recommends to his Roman $\mathrm{Ca}$ tholic friends, and Clemens von Brentano's "Frühlingsschrei eines Knechtes aus der Tiefe", a poem of 1816. This is of special interest since, it seems to me, the voice of Brentano's remarkable poem, filled with despair at the world but never losing faith in the greater cosmic vision, can be heard somewhere behind Wolfskehl's poems in Die Stimme spricht and even in the voice of his Job poems. Francis Thompson's dramatic image of God's grace being visible in any and every situation is more likely to be parallel to Wolfskehl's religious vision than an influence on it.

This letter to Salin of August 1942 shows that by this time Wolfskehl was absorbed in his contemplative and intense study of poetry in English of the preceding thirty or forty years. Some weeks later

6 To Edgar Salin, 3 August 1942, BaN II, 160.

7 To Father Michels, 15 December 1942, 282. 
he remarks to a friend in America: "for some time now I have known a bit more about modern American matters [...] I take T. S. Eliot extremely seriously." 8 And he begs the friend to send him Eliot's latest work, a "war poem" he has heard of (presumably the last three of the Four Quartets). A little later again he says that he is "expanding [his] knowledge of recent and most recent AngloAmerican literary movements, especially the lyrical developments, which have now completely abandoned the paths pursued by Swinburne and pre-Raphaelite idealism."9 Now, for the first time, he modifies his praise of Eliot by saying that there is another line of development which is at least as important, namely that leading to Brennan in Australia and possibly to Hart Crane in America. He asks whether these figures might not be peaks from which it will be possible to see a new country, a more hopeful future than that suggested by - it is implied - the Eliot tradition.

A letter of December shows that Wolfskehl had been working not only on Eliot's poems but also on his essays.10 Not surprisingly, Eliot's views of Swinburne are especially interesting and especially enlightening to Wolfskehl. He says that these views show "the penetrating and subtle tact of [Eliot's] feeling for the poetic most clearly and at the same time with their strangely rationalistic rejection of Swinburne's work also show the state of things of the soul in this sphere most clearly." Wolfskehl also makes reference to John Donne here and elsewhere, and it seems that he views Donne as someone born before his time, who has many of the same concerns as Wolfskehl himself and the twentieth century in general. Thèsè lêttèrs of 1942 rēprèsēnt the mōst intense occupation of Wolfskehl with English-language poetry. During the next two years references to these matters tend to echo those already quoted and in the last years of his life, on the evidence available, Wolfskehl seems to have found what he was seeking and then to have turned back to his continental - and cosmic - interests. In March 1943 he says that he knows "all of Eliot's essays" and calls him "a sublime mind". But again he expresses certain reservations, saying "at times he plays with his object rather than embracing it lovingly and he shifts it into a point of light which burns up rather than illuminates the apparent and consequently only validity". By this time Wolfskehl is also less tolerant of Eliot's view of Swinburne.11 This view of

8 To Carla and Kurt Heinrich Wolff, 19 October 1942, BaN II, 469.

9 To Wolfgang Jablonski, 4 November 1942, BaN II, 360.

10 To Hans Brasch, 17 December 1942; BaN II, 416-8.

11 To Runhilt von den Steinen, 31 March, 1943, BaN II, 521-2. 
Eliot anticipates Wolfskehl's somewhat dismissive general comment on the Anglo-American approach to things, which is his last (available) summing up of these matters, made in July 1944 in a letter to Ernst Gundolf.12 "Your judgement [of Eliot] coincides completely with mine although I would never have been able to express it so concisely, and a completely new point is the way you derive it from the general unwillingness 'to be ernest'.13 I have collected the most astonishing examples of this in private life and in everyday life as well, to the extent that I have any contact at all. The good side of this tendency, which goes back a long way in secular matters, reaches a climax in Swift or Sterne and is still occasionally amusing in its decay in Wilde or Shaw." He mentions such challenges to be superficially clever as a sonnet competition in the $\mathrm{New}$ Statesman, whose results, he finds, revert to the age of Oliver Goldsmith, and he concludes these sentences on the lack of "ernestness" in those who speak English with his strongest attack on Eliot: "Only from this point of view can one explain or understand the stubborn way they reject their last true poet of world rank, Swinburne, in whose work even Edith Sitwell, so over-eager as she is in technical matters and so fine in her senses of hearing and touch, fails to find what is true, and T. S. Eliot, for all his clever way of imitating respect, fails to find anything at all."

One has to conclude that Wolfskehl's adventure in English literature passed through a phase of excitement and admiration into some kind of disillusionment.

In his letters we also find a range of references to modern Englishspeaking literary scholars and commentators, mainly because of what they have to say about German poetry and more specifically George. The writer of this kind he finds most attractive is C. M. Bowra, whose book The Heritage of Symbolism (1943) contains a chapter on George. Wolfskehl comments frequently on this and says at one point: "The Heritage of Symbolism with its apparently widely appreciated essay on George, which seems characteristic to me, including in the narrow limits of its approach, [is] what I call [a] significant achievement." $14 \mathrm{He}$ also found praise for a thesis on French Symbolism in Germany written in French by the English scholar Enid Duthie. On the other hand E. M. Butler's study of the Greek influence on German literature comes in for some sharp criticism.

1211 July 1944, BaN II, 441.

13 In English (and so spelled) in the original.

14 To Helmut von den Steinen, 24 April 1942, BaN II, 232. 
Repeatedly, however, the major comment Wolfskehl makes is that the work of Rilke is overvalued in the English-speaking world and that of George undervalued. This emerges especially when he comments on the way Stephen Spender evaluates German literature. Typical is this comment from a letter of 1944: "I also enthuse over Stephen Spender, and this feeling is not seriously affected by his rather childish attitude to George and especially to his Circle. I just have to smile when he defends poor unprotected Rainer Rilke from the nastiness of that Circle - it is well known that Rilke and I were close to each other and on good terms. By the way I have passed on a message to this effect to Spender through a highly intelligent and charming Englishwoman who knows him and I am curious to see how he will react." 15

There seems to be no record of Spender's reaction, but the "charming Englishwoman" can be identified as Mrs. Pia Richards, the daughter, as Wolfskehl emphasises in several letters, of the English novelist Maurice Hewlett. Wolfskehl expresses deep gratitude to her in several of the 1942 letters, and it is clear that she is one of the intermediaries who was able to introduce him to the literature addressed in this paper. In fact his friendship with her continued for several years, and he describes her fondly in a letter of 1946: "If someone I meet here comes directly from England, we always understand each other [...] the closest of them is a wonderful woman, the daughter of Maurice Hewlett - you might have read one of his novels sometime in the past, or his thick book on Tuscany that awakens all one's longing. She has been living here for thirty years with a husband who is permitted to come home at weekends, children, all sorts of in-laws to the third generation, and she comes twice a week to read to me. Those are then very full mornings, full of wit and sarcasm and I learn an enormous amount from them. Her personal memories go back to the two Huxleys, Edmond Gosse, Matthew Arnold, an uncle of her mother, who recently died here at the age of 100 , and also to that malicious-gracious Hilaire Belloc. So at least with her one can live in a real world of memories." 16 Other Aucklanders were also happy to read to Wolfskehl and discuss what they read. One of them was Frank Sargeson, who brought potatoes and cabbages from his garden and books from his shelves. Another was Rex Fairburn. Yet another the young John Graham. As we have seen, Wolfskehl was in personal contact with people

15 To Helmut von den Steinen, 18 April 1944, BaN II, 228.

16 To Gertrud Countess Helmstatt, 1 November 1946, BaN III, 897. 
from the Caxton Press both in Christchurch and in Auckland, and these friends also made him familiar with recent New Zealand writing. Those he admired most were Rex Fairburn, Allen Curnow and Frank Sargeson. At one time he tried to arrange a meeting between Ernst Gundolf and Dennis Glover in London.17

Other poets who have not been mentioned in the framework of this paper but who played an important role in Wolfskehl's imaginative life during his Auckland years are W. B. Yeats, Ezra Pound, and Robert Graves. As Paul Hoffmann wrote in the introduction to the Briefwechsel: "One can hardly understand how a man, who was unable to read and depended completely on people reading to him, managed to discover and to make his own, entirely through his ears, a major part of English poetry."

17 Dependence on Wolfskehl's correspondence for identifying these figures can be misleading, since there is much evidence of a long friendship with the New Zealand poet R. A. K. Mason, who is never mentioned in the letters. Also rarely mentioned is Paul Hoffmann, who visited Wolfskehl weekly for several years while studying for the M.A. in English and consequently reported in detail to the poet on what was being said and what was being valued in the English Department of the University of Auckland - I am grateful to Hansgerd Delbrück for pointing this out. 